\title{
PENGARUH PEMBELAJARAN MENGGUNAKAN MULTIMEDIA ANIMASI TERHADAP PENINGKATAN PENGUASAAN KONSEP MATERI GAYA PADA SISWA SMK
}

\author{
Ari Ridwan ${ }^{1}$, Dedi Supriawan ${ }^{2}$, Ariyano $^{3}$ \\ Universitas Pendidikan Indonesia \\ Jl. Dr. Setiabudhi 229 Bandung 40154 \\ ariread1@yahoo.com
}

\begin{abstract}
ABSTRAK
Penelitian ini bertujuan untuk mengetahui pengaruh pembelajaran menggunakan multimedia animasi terhadap peningkatan penguasaan konsep siswa SMK pada materi gaya dengan metode multimedia animasi dibandingkan dengan media diktat. Metode penelitian yang digunakan adalah metode kuasi eksperimental dengan desain nonequivalent control group design. Pengumpulan data dilakukan menggunakan tes pilihan ganda, tes dilakukan sebelum dan sesudah siswa diberikan treatment. Hasil penelitian yang dilihat dari nilai rata-rata N-Gain dari masing-masing kelompok menunjukkan pengaruh penggunaan multimedia animasi terhadap peningkatan penguasaan konsep. Kelas yang menggunakan multimedia animasi berada pada kategori sedang, sedangkan kelas yang menggunakan media diktat yang berada pada kategori rendah, sehingga terlihat terdapat pengaruh penggunaan multimedia animasi terhadap peningkatan penguasaan konsep pada pembelajaran materi gaya.
\end{abstract}

Kata kunci: multimedia animasi, penguasaan konsep, mekanika, gaya.

\section{PENDAHULUAN}

Pendidikan bagi sebagian besar orang, berusaha membimbing anak untuk menyerupai orang dewasa. Pendidikan berarti menghasilkan, mencipta, sekalipun tidak banyak, sekalipun suatu penciptaaan dibatasi oleh pembandingan dengan penciptaan yang lain (Sagala, 2014). Pendidikan sebagai penghubung dua sisi, disatu sisi individu yang sedang tumbuh dan disisi lain nilai sosial, intelektual, dan moral yang menjadi tanggung jawab pendidik untuk mendorong individu tersebut. Individu berkembang sejak lahir dan terus berkembang, perkembangan ini bersipat kausal. Namun terdapat komponen normatif, juga karna pendidik menuntut nilai. Nilai ini adalah norma yang berfungsi sebagai dalam mengidentifikasi apa yang diwajibkan, diperboleh dan dilarang. Pendidikan adalah hubungan normative antara individu dan nilai.

Pandangan tersebut memberi makna bahwa pendidikan adalah segala situasi hidup yang mempengaruhi pertumbuhan individu sebagai pengalaman belajar berlangsung dalam segala

\footnotetext{
${ }^{1}$ Mahasiswa Departemen Pendidikan Teknik Mesin FPTK, UPI

2 Dosen Departemen Pendidikan Teknik Mesin FPTK, UPI

${ }^{3}$ Dosen Departemen Pendidikan Teknik Mesin FPTK, UPI
} 
lingkungan dan sepanjang hidup. Pengalaman dalam arti sempit pendidikan adalah pengajaran yang diselenggarakan umumnya disekolah sebagai lembaga pendidikan formal.

Sekolah pada umumnya menjadi tempat untuk mencari, mengembangkan, dan juga membekali siswa dengan kompetensi agar siswa dapat menyesuaikan dirinya dengan perubahan yang ada. Dengan demikian proses belajar disekolah diharapkan dapat membuat siswa belajar untuk berpartisipasi aktif dengan konsep-konsep dan prinsip-prinsip. Siswa akan mengalami proses belajar yang menambah pengetahuan serta meningkatkan kemampuan menghubungkan pengetahuan tersebut dengan situasi yang sedang dihadapi (Dahar, 2011). Apabila hal tersebut dapat dilaksanakan siswa, siswa akan mencapai hasil belajar yang baik.

Sekolah Menengah Kejuruan (SMK) merupakan salah satu lembaga pendidikan formal yang tujuannya menyiapkan siswa menjadi calon tenaga kerja yang terampil dan produktif untuk bekerja pada bidangnya. Untuk bekerja, tidak hanya keterampilan yang dilihat tetapi siswa harus dibekali dengan kepribadian yang bermoral dan beretika (Djamarah \& Zain, 2006). Dengan kata lain ada keseimbangan antara hardskill dan softskill yang dapat meningkatkan sikap profesional.

SMKN 6 Bandung khususnya di Jurusan Teknik Mesin, mempelajari mata pelajaran mekanika yang harus benar-benar dikuasai dan dipahami agar tidak mengalami kesulitan utuk melanjutkan kejenjang pendidikan yang lebih tinggi ataupun kedunia kerja. Pokok utama dari ilmu mekanika mempelajari perilaku struktur terhadap beban yang bekerja maka hal-hal yang banyak dibicarakan adalah stabilitas, keseimbangan gaya, dan kompatibilitas antara deformasi. Dengan mengetahui gaya-gaya dan lendutan yang terjadi maka selanjutnya struktur tersebut dapat direncanakan atau diproporsikan dimensinya berdasarkan material yang digunakan sehingga aman dan nyaman dalam menerima lendutannya tidak berlebihan beban tersebut. Sedangkan permasalahan dalam pembelajaran mekanika teknik yaitu siswa kesulitan memahami konsep yang abstrak, sehingga materi gaya-gaya termasuk pokok bahasan yang sulit dipahami siswa.

Pembelajaran mekanika tujuannya tidak lepas dari upaya untuk menigkatkan kemampuan siswa agar mampu mengimplementasikan ilmu yang diperolehnya dengan baik. Tingkat penguasaan siswa terhadap ilmu mekanika dipengaruhi oleh banyak faktor, diantaranya motivasi, prasarana, media pembelajaran, sumber belajar. Sumber pembelajaran yang digunakan SMKN 6 Bandung yaitu menggunakan diktat yang lebih mengarah guru 
sebagai pusat belajar tentunya hal ini akan berpengaruh pada penguasaan siswa terhadap materi pokok bahasan yang abstraks (Sanjaya, 2010).

Imbas dari sumber media yang digunakan mempengaruhi pada pencapaian hasil belajar yag kurang optimal. Hal tersebut dapat dilihat dari hasil belajar nilai ujian tengah semester mata pelajaran mekanika teknik semester ganjil. Hasil Ujian Tengah Semester pada mata pelajaran mekanika teknik kelas X/TPM. Data di atas dapat dilihat bahwa nilai mekanika teknik memiliki standar kelulusan minimal 2,0 sedangkan dari data yang diperoleh yang tergolong gagal mencapai 15 siswa atau 48,39\%, persentse siswa yang mendapatkan nilai cukup 9 siswa atau 29,03\%, persentase siswa yang tergolong baik 4 siswa atau 12,9\%, dan siswa yang tergolong amat baik yaitu 3 siwa atau 9,68\%. Dengan melihat hasil distribusi nilai mekanika disimpulkan bahwa hasil terebut dipengaruhi oleh faktor media pembelajaran yaitu dengan menggunakan diktat, mekanika banyak membahas hal-hal yang bersifat abstrak, yang menyebabkan siswa kesulitan berimajinasi atau mengilustrasikan gaya yang bekerja.

Ada beberapa faktor yang menghambat proses belajar yaitu akibat tidak suka rumus atau hitungan, susah menghapal rumus atau rumus sering tertukar dan susah untuk berimajinasi serta pada pokok bahasan gaya memiliki karakteristik abstrak dikarnakan dalam proses pembelajaran menggunakan diktat. Penggunaan multimedia animasi dapat memicu semangat belajar dan hasil belajar yang baik (Rusman, 2012). Pokok bahasan gaya menitik beratkan pada jenis konsep relasional yang merupakan bagian dari jenis konsep struktur. Dimana pada konsep jenis ini siswa harus dapat menyatakan hubungan yang terjadi pada setiap atribut konsep yang ada. Konsep tersebut harus dikuasai dengan baik, sehingga siswa dapat memahami pokok bahasan yang diajarkan.

Hasil studi pendahuluan, bisa diketahui bahwa faktor yang menyebabkan siswa mengalami kesulitan dalam pembelajaran mata pelajaran mekanika yaitu karena kesulitan memahami konsep yang abstraks. Hal tersebut disebabkan karena pada mata pelajaran Mekanika banyak membahas hal-hal yang bersifat abstraks dan hitungan yang menyebabkan siswa kesulitan berimajinasi atau mengilustrasikan gaya yang bekerja. Agar siswa dapat menguasai materi Mekanika khususnya pokok pembahasan gaya yang dianggap kurang memahami perlu dilakukan upaya perbaikan proses pembelajaran yang tidak lagi sulit walaupun tidak langsung dipahami namun tidak membosankan jika dilakukan berulang-ulang atau dipelajari sendiri sehingga hasil akhirnya dapat dikuasai dengan baik, salahsatu upaya 
memperbaiki kesulitan itu dengan pemanfaatan pembelajaran menggunakan multimedia animasi terhadap peningkatan penguasaan konsep materi gaya pada mata pelajaran mekanika teknik.

\section{METODE PENELITIAN}

Metode penelitian menggunakan kuasi eksperimental dengan design nonequivalent control group design. Pada desain ini kedua kelompok yaitu kelompok eksperimen dan kontrol masing-masing diberikan pre-test untuk mengetahui keadaan awal dari sampel dan untuk mengetahui adanya perbedaan antara kelompok eksperimen dan kelompok kontrol. Dalam hal ini eksperimen diharapkan dapat mengungkapkan perbedaan hasil belajar dengan menggunakan diktat dibandingkan dengan menggunakan multimedia animasi.

\section{HASIL PENELITIAN}

Hasil uji homogenitas yang menunjukkan bahwa varian kedua kelompok homogen, maka pengujian pada penelitian ini dapat dilanjutkan menggunakan analisis data Statistik Parametrik metode uji t dan jumlah anggota sampel $n 1=n 2$ dan varian homogen $(\sigma 12=\sigma 22)$ maka dapat digunakan rumus t-test. Untuk melihat harga t-tabel digunakan $d k=n 1+n 2-2$. Hasil pengolahan data untuk menjawab rumusan hipotesis, yaitu uji N-Gain, dan uji t.

Uji t pada tabel 2 yang dilakukan terhadap data N-Gain kelompok kontrol dan kelompok eksperimen dengan taraf signifikansi $\alpha=0,05$, dan pengujian output SPPS menghasilkan nilai Asymp sig. 2 (tailed) sebesar 0,290, dikarnakan P-value lebih besar dari alpha $(0,290>0,05)$ dan $t-1,068$ Berdasarkan perbandingan nilai yang didapat Ho diterima artinya terdapat perbedaan sig. Data N-Gain pada kelompok kontrol dan eksperimen.

Uji $N$-Gain diperoleh bahwa Ho ditolak dan Ha diterima, artinya N-Gain kelompok eksperimen lebih baik daripada N-Gain kelompok kontrol. Pengambilan keputusan bahwa Ho ditolak dan Ha diterima, didukung oleh hasil perhitungan nilai p-value. Berdasarkan nilai pvalue $(0,29)>\alpha(0,05)$, Ha diterimaa, karena resiko sebesar 0,29\% lebih kecil daripada taraf signifikansi yang telah ditetapkan yaitu $5 \%$ dan nilai t $(-1,068)$ lebih kecil dari alpha. Hasil dari uji t, maka dapat dikatakan H0 ditolak dan Ha diterima, bahwa penggunaan multimedia animasi berpengaruh terhadap penguasaan konsep siswa pada pembelajaran materi gaya. 


\section{PEMBAHASAN}

Pengaruh pembelajaran menggunakan multimedia animasi memberikan peningkatan penguasaan konsep siswa mengenai materi gaya yang lebih baik dibandingkan dengan pembelajaran menggunakan diktat. Diketahui bahwa kelas kontrol menggunakan diktat dan kelas eksperimen menggunakan multimedia Animasi. Kurangnya media belajar yang diterima oleh siswa materi gaya selama proses pembelajaran sehinggga kurang menimbulkan pengalaman belajar. Media yang digunakan diktat sehingga dinilai tidak terjangkau (inaccessible) yang membuat siswa kurang mampu menangkap materi dengan maksimal, selain itu juga kesulitan siswa yang menggunakan diktat sulit dalam memahami rumus materi gaya akibat siswa tidak suka rumus yang cukup banyak (Susilana \& Riyana, 2009).

Siswa yang menggunakan media diktat pada proses pembelajarannya memiliki hasil penguasaan konsep yang lebih rendah jika dibandingkan dengan hasil penguasaan konsep siswa yang menggunakan animasi. Hal ini berkaitan dengan karakter yang dimiliki oleh diktat sebagai media belajar.

Hasil penelitian ini menunjukkan bahwa adanya pengaruh terhadap penguasaan konsep siswa yang diberikan pembelajaran dengan menggunakan diktat rendah. Ini ditunjukkan dengan hasil post-test dan nilai rata-rata N-Gain (Sukardi, 2011). Diketahui bahwa kelas kontrol diberikan pembelajaran dengan menggunakan diktat. Peningkatan hasil belajar kelas kontrol dengan hasil perhitungan menggunakan uji t, yang menghasilkan keputusan Ho ditolak, yang artinya N-Gain kelompok kontrol rendah daripada N-Gain kelompok eksperimen. Pengambilan keputusan bahwa Ho ditolak, didukung oleh hasil perhitungan nilai p-value pada uji t. Nilai p-value yang lebih kecil dari nilai $\alpha$, sehingga menolak Ho dan menerima Ha. Peningkatan penguasaan konsep siswa pada materi gaya yang menggunakan diktat ditolak.

Karakteristik materi gaya merupakan konsep yang sulit dijelaskan jika dengan menggunakan gambar atau kata-kata saja. Sehingga peningkatan penguasaan konsep dengan menggunakan media diktat sulit meningkat. Uraian pembahasan diatas dapat memberikan gambaran bahwa terdapat pengaruh penggunaan diktat terhadap peningkatkan penguasaan konsep menggunakan diktat dengan hasil yang rendah.

Rendahnya peningkatan hasil belajar pada kelompok kontrol yang menggunakan media diktat tidak terlepas dari penyajian media tersebut. Penyajian media tersebut salah satunya 
adalah kurang dapat menjelaskan teori gaya. Pada materi definisi materi gaya media menggunakan diktat hanya menyajikan visualisasi gaya tarik yang diam, sehingga tidak dapat memperjelas dan mempermudah siswa untuk memahami materi pembelajaran dengan baik.

Kurangnya media belajar yang diterima oleh siswa materi gaya selama proses pembelajaran sehinggga kurang menimbulkan pengalaman belajar. media yang digunakan diktat sehingga dinilai tidak terjangkau (inaccessible) yang membuat siswa kurang mampu menangkap materi dengan maksimal.selain itu juga kesulitan siswa yang menggunakan diktat sulit dalam memahami rumus materi gaya akibat siswa tidak suka rumus yang cukup banyak.

Peningkatan penguasaan konsep siswa yang menggunakan multimedia animasi dalam proses pembelajarannya berkaitan dengan ciri dan karakteristik dari multimedia animasi itu sendiri. Multimedia animasi termasuk kedalam media hasil penggabungan teknologi cetak dan komputer yang menggabungkan antara teks, gambar atau visual yang statis dan dinamis serta audio yang semua ini dikendalikan oleh komputer, sehingga dalam prosesnya melibatkan banyak interaktivitas (Arsyad, 2010). Hal tersebut dipengaruhi dari hasil manipulasi teoritis (gambar).

Pengaruh terhadap penguasaan konsep siswa yang diberikan pembelajaran dengan menggunakan multimedia animasi. Ini ditunjukkan dengan hasil post-test dan nilai rata-rata $\mathrm{N}$ Gain kelas eksperimen yang lebih besar nilainya dibandingkan dengan kelas kontrol. Diketahui bahwa kelas eksperimen diberikan pembelajaran menggunakan multimedia animasi. Peningkatan hasil belajar dari kelompok eksperimen sejalan dengan hasil perhitungan menggunakan uji t, yang menghasilkan keputusan Ha diterima, yang artinya N-Gain kelompok eksperimen lebih baik daripada N-Gain kelompok kontrol. Pengambilan keputusan bahwa Ha diterima, didukung oleh hasil perhitungan nilai p-value pada uji t. Berdasarkan nilai p-value yang lebih kecil dari nilai $\alpha$, sehingga peneliti berani menerima Ha. Berdasarkan hal tersebut, peningkatan penguasaan konsep siswa pada materi gaya yang menggunakan multimedia animasi dapat dikatakan lebih baik daripada peningkatan penguasaan konsep siswa yang menggunakan media diktat (Sudjana, 2010).

Peningkatan penguasaan konsep pada kelompok eksperimen tidak lepas dari penjelasan multimedia animasi yang lebih konkret dibandingkan dengan media diktat. Semakin konkret penjelasan sebuah media pembelajaran pada suatu proses pembelajaran, maka akan semakin 
banyak pengalaman yang didapat oleh peserta didik. Penggunaan media pembelajaran yang lebih konkret akan menghasilkan peningkatan penguasaan konsep yang lebih baik.

Kurangnya media belajar yang diterima oleh siswa materi gaya selama proses pembelajaran sehinggga kurang menimbulkan pengalaman belajar. Media yang digunakan diktat sehingga dinilai tidak terjangkau (inaccessible) yang membuat siswa kurang mampu menangkap materi dengan maksimal. Selain itu juga kesulitan siswa yang menggunakan diktat sulit dalam memahami rumus materi gaya akibat siswa tidak suka rumus yang cukup banyak.

Pengaruh pembelajaran menggunakan multimedia animasi memberikan peningkatan penguasaan konsep siswa mengenai materi gaya yang lebih baik dibandingkan dengan pembelajaran menggunakan diktat. Diketahui bahwwa kelas kontrol menggunakan diktat dan kelas eksperimen menggunakan multimedia Animasi.

Hasil penelitian ini menunjukkan bahwa adanya pengaruh terhadap penguasaan konsep siswa yang diberikan pembelajaran dengan menggunakan multimedia animasi. Ini ditunjukkan dengan hasil post-test dan nilai rata-rata N-Gain kelas eksperimen yang lebih besar nilainya dibandingkan dengan kelas kontrol. Diketahui bahwa kelas eksperimen diberikan pembelajaran menggunakan multimedia animasi sedangkan kelas kontrol diberikan pembelajaran dengan menggunakan diktat. Pada proses pembelajaran dari masing-masing kelompok.

Perbedaan peningkatan hasil belajar dari kedua kelompok juga sejalan dengan hasil perhitungan menggunakan uji t, yang menghasilkan keputusan Ha diterima, yang artinya NGain kelompok eksperimen lebih baik daripada N-Gain kelompok kontrol. Pengambilan keputusan bahwa Ha diterima, didukung oleh hasil perhitungan nilai p-value pada uji t. Nilai p-value yang lebih kecil dari nilai $\alpha$, sehingga menerima Ha. Peningkatan penguasaan konsep siswa pada materi gaya yang menggunakan multimedia animasi dapat dikatakan lebih baik daripada peningkatan penguasaan konsep siswa yang menggunakan media diktat. Penggunaan media diktat maupun multimedia animasi pada pembelajaran, dapat meningkatkan penguasaan konsep siswa. Hal ini didukung oleh data penelitian dengan melihat peningkatan nilai hasil belajar siswa setelah mendapatkan treatment dari kelompok kontrol maupun kelompok eksperimen. Media meningkatkan kemampuan keterbacaan baru (Arsyad, 2010).

Rendahnya peningkatan hasil belajar pada kelompok kontrol yang menggunakan media diktat tidak terlepas dari penyajian media tersebut. Penyajian media tersebut salah satunya 
adalah kurang dapat menjelaskan teori gaya. Pada media animasi materi definisi gaya salah satunya memberikan contoh dari proses gaya yang terjadi pada gaya tarik, sedangkan media diktat hanya menyajikan visualisasi gaya tarik yang diam, animasi tersebut akan lebih memperjelas dan mempermudah siswa untuk memahami materi pembelajaran dengan baik. Berdasarkan penjelasan penyajian media, dapat dikatakan bahwa pembelajaran pada materi gaya ini dapat dipahami jika dibantu dengan animasi, sedangkan tanpa media animasi proses pembelajaran pada pergerakan gaya ini tidak dapat dilakukan dengan optimal (Splittgerber \& Stirzaker, 2004). Peningkatan penguasaan konsep pada kelompok eksperimen tidak lepas dari penjelasan multimedia animasi yang lebih konkret dibandingkan dengan media diktat. Penggunaan media pembelajaran yang lebih konkret akan menghasilkan peningkatan penguasaan konsep yang lebih baik.

Karakteristik materi gaya, materi merupakan materi gaya dengan konsep yang sulit dijelaskan dengan menggunakan gambar atau kata-kata saja. Sehingga peningkatan penguasaan konsep dengan menggunakan multimedia animasi akan lebih baik daripada peningkatan penguasaan konsep dengan menggunakan media diktat. Hasil penelitian ini memberikan gambaran bahwa terdapat pengaruh penggunaan Multimedia Animasi terhadap peningkatkan penguasaan konsep siswa pada pembelajaran materi gaya jika dibandingkan dengan media yang hanya berupa diktat.

\section{KESIMPULAN}

Penelitian ini dapat disimpulan sebagai berikut: peningkatan penguasaan konsep siswa dalam pembelajaran materi gaya pada mata pelajaran Mekanika Teknik dengan menggunakan diktat berada dalam kategori rendah. Peningkatan penguasaan konsep siswa dalam pembelajaran materi gaya pada mata pelajaran Mekanika Teknik dengan menggunakan multimedia animasi berada dalam kategori sedang. Terdapat perbedaan peningkatan penguasaan konsep materi gaya pada siswa yang menggunakan multimedia animasi dibandingkan dengan siswa yang menggunakan diktat, dimana yang menggunakan multimedia animasi lebih tinggi daripada menggunakan diktat.

\section{REFERENSI}

Arsyad A. (2010). Media Pembelajaran. Jakarta: PT. Raja Grafindo Persada. 
Dahar, R.W. (2011). Teori-teori Belajar dan Pembelajaran, Jakarta: Erlangga.

Djamarah, S.B. \& Zain, A. (2006). Strategi Belajar Mengajar. Jakarta: Rineka Cipta.

Rusman, et. al. (2012). Pembelajaran Berbasis Teknologi Informasi dan Komunikasi Mengembangkan Profesionalitas Guru. Jakarta: PT. Raja Grafindo Persada.

Sagala, S. (2014). Konsep dan Makna pembelajaran. Bandung: Alfabetha.

Sanjaya, W. (2010). Perencanaan dan Desain Sistem Pembelajaran. Jakarta: Kencana Perdana Media Group.

Splittgerber, F.L., \& Stirzaker N.A. (2004). Computer Technology for Administrative Information and Instructional Management in School Districts. Educational Technology, (XXIV) 2.

Sudjana, N. (2010). Penilaian Hasil Proses Belajar Mengajar. Jakarta: Remaja Rosdakarya.

Sukardi, M.S. (2011). Evaluasi Pendidikan (Prinsip dan Operasionalnya). Jakarta: Bumi Aksara.

Susilana, R. \& Riyana, C. (2009). Media Pembelajaran. Bandung: CV. Wacana Prima. 